\title{
PEMBELAJARAN ONLINE BERBASIS PROYEK SALAH SATU SOLUSI KEGIATAN BELAJAR MENGAJAR DI TENGAH PANDEMI COVID-19
}

\author{
Zainal Abidin ${ }^{1}$, Rumansyah ${ }^{2}$, Kurniawan Arizona ${ }^{3 *}$ \\ ${ }^{1}$ Kantor Cabang Dinas Pendidikan dan Kebudayaan Lombok Timur NTB \\ ${ }^{2}$ SMAN 1 Mataram, Nusa Tenggara Barat \\ ${ }^{3}$ Progaram Studi Tadris Fisika, Fakultas Tarbiyah dan Keguruan UIN Mataram, Indonesia \\ *Corresponding Author: arizona@uinmataram.ac.id
}

\section{Artikel History}

Received: 30 April 2020

Revised: 01 Mei 2020

Accepted: 02 Mei 2020

Published: 10 Mei 2020
Abstrak: Perubahan pola pembelajaran saat ini terlihat masif dilakukan di semua jenjang pendidikan akibat pandemi Covid-19. Penelitian ini bertujauan untuk mengupas secara teoritis berdasarkan studi pustaka pembelajaran online berbasis proyek di tengah pandemi Covid-19 yang berefek pada kebijakan belajar di rumah. Sistem pembelajaran online berbasis proyek memberikan banyak peluang untuk mengakses bahan ajar oleh warga pembelajar. Banyak flatform maupun media online yang bisa diakses melalui jaringan internet oleh pengajar maupun peserta didik. Beberapa flatform gratis yang sudah terbukti efektif dalam pengelolaan pembelajaran online secara klasikal diantaranya adalah Google Classroom dan Edmodo. Setidaknya ada 12 aplikasi gratis lainnya sebagai media dan sumber belajar online yang dapat dimanfaatkan di tengah pandemi Covid-19 yaitu Rumah Belajar, Meja Kita, Icando, Indonesia X, Google for Education, Kelas Pintar, Microsoft Office 365, Quipper School, Ruangguru, Sekolahmu, Zenius dan Cisco Webex. Beberapa hal yang menjadi kendala dalam penerapan pembelajaran online diantaranya kuota internet yang terbatas dan masih belum familiarnya tenaga pendidik beserta peserta didik dalam mengaplikasikannya. Oleh karena itu perlu adanya upaya khusus yang lebih masif untuk mengatasi problematika ini mulai dari individu masing-masing, dukungan keluarga, lembaga/institusi pendidikan, jasa provider dan pemerintah. Salah satu pendekatan pembelajaran yang dapat memaksimalkan pembelajaran online adalah pembelajaran berbasis proyek. Pembelajaran ini memberikan peluang kepada peserta didik untuk mempelajari konsep secara mendalam sekaligus juga dapat meningkatkan hasil belajar mereka.

Kata kunci: Pembelajaran Online, Pembelajaran Berbasis Proyek, Covid-19

Abstract: Changes in learning patterns currently seem massive in all levels of education due to the Covid-19 pandemic. This research aims to explore the theoretically-based library study on project-based online learning amid the Covid19 pandemic that affects home learning policies. The project-based online learning system provides many opportunities to access teaching materials by learning citizens. Many online platforms and media can be accessed through the internet by teachers and students. Some of the free platforms that have been proven to be effective in managing online classically learning include Google Classroom and Edmodo. There are at least 12 other free applications as media and online learning resources that can be utilized during the Covid-19 pandemic. Those are Rumah Belajar, Meja Kita, Icando, Indonesia X, Google for Education, Smart Class, Microsoft Office 365, Quipper School, Ruangguru, Sekolahmu, Zenius, and Cisco Webex. Some things that become obstacles in the application of online learning include limited internet quota and the unfamiliar teaching staff and students in applying it. So that there is a need for more massive special efforts to overcome this problem, they were starting from each individual, family support, educational institutions, service providers, and government. One learning approach that can maximize online learning is project-based learning. This learning provides opportunities for students to learn concepts in depth while also being able to improve their learning outcomes.

Keywords: Online Learning, Project-Based Learning, Covid-19 


\section{PENDAHULUAN}

Revolusi Industri 4.0 merupakan keadaan industri abad ke-21 saat perubahan besar-besaran di berbagai bidang lewat perpaduan teknologi yang mengurangi sekat-sekat antara dunia fisik, digital, dan biologi. Seperti yang dipaparkan Kagerman et al. (2011), Revolusi Industri 4.0 lahir di Negara Jerman pada Tahun 2011. Kini berbagai industri mulai menyentuh dunia virtual, berbentuk konektivitas manusia melalui mesin, perangkat, sensor dan data yang lebih dikenal dengan nama Internet of Things (IoT) (Herman, et al., 2016). Terkait dampak Revolusi Industri 4.0 yakni dengan adanya 'digitalisasi sistem', menuntut para pendidik dan peserta didik untuk mampu dengan cepat beradaptasi dengan perubahan yang ada. Sistem pembelajaran yang semula berbasis pada tatap muka secara langsung di kelas, bukan tidak mungkin akan dapat digantikan dengan sistem pembelajaran yang terintegrasikan melalui jaringan internet (online learning). Pembelajaran online menghubungkan pembelajar (peserta didik) dengan sumber belajarnya (database, pakar/instruktur, perpustakaan) yang secara fisik terpisah atau bahkan berjauhan namun dapat saling berkomunikasi, berinteraksi atau berkolaborasi (secara langsung/synchronous dan secara tidak langsung/asynchronous). Pembelajaran online merupakan bentuk pembelajaran/pelatihan jarak jauh yang memanfaatkan teknologi telekomunikasi dan informasi, misalnya internet, CD-ROOM (secara langsung dan tidak langsung) (Molinda, 2005).

Pembelajaran online tentunya akan kurang bermakna tanpa sinergitas strategi dan metode pembelajaran yang tepat. Salah satu penerapan yang dapat memadukan pembelajaran online adalah pembelajaran berbasis proyek. Komponen utama pembelajaran berbasis proyek adalah mengajukan pertanyaan atau masalah yang disajikan untuk menyusun dan memulai aktivitas yang menekankan kepada sejumlah proyek sampai didapatkannya hasil akhir berupa produk sebagai rangkaian aktivitas komunikasi individu atau berbagai hasil tugas yang menjawab pertanyaan. Sehingga melaui pembelajaran berbasis proyek memberikan peluang kepada peserta didik untuk mempelajari konsep secara mendalam sekaligus juga dapat meningkatkan hasil belajar mereka. Sebagaimana yang dinyatakan Sucilestari dan Arizona (2018) pembelajaran berbasis proyek merupakan investigasi mendalam tentang sebuah topik dari dunia nyata. Proyek yang dirancang dengan baik meminta peserta didik untuk mengatasi masalah nyata dan isu-isu penting yang terjadi dalam kehidupan sehari-hari khususnya dalam proses pembelajaran. Dengan demikian, proyek-proyek yang dibangun peserta didik berdasarkan pengamatan terhadap permasalahan dunia nyata di sekitar mereka yang akan memberikan kebermaknaan bagi mereka.

Berdasarkan hal ini perlu adanya pembelajaran yang efektif diterapkan terhadap peserta didik untuk meningkat kompetensi mereka. Terlebih lagi akibat dari dampak pandemik Covid-19 yang melanda sehingga pembelajaran tidak berjalan maksimal karena harus tetap di rumah dan menerapkan physical distancing. Sehingga pembelajaran online berbasis proyek menjadi salah satu solusi terhadap masalah yang dihadapi untuk menjawab permasalahan ini.

\section{METODE}

Penelitian ini termasuk dalam studi literatur. Jenis data yang dikumpulkan berupa data sekunder berupa hasil-hasil penelitian dari berbagai artikel, sumber pustaka dan dokumen yang sesuai dengan tema pembelajaran online dan berbasis proyek. Sebagaimana yang dinyatakan oleh Zed (2014), pada riset pustaka (library research), penelusuran pustaka tidak hanya untuk langkah awal menyiapkan kerangka penelitian (research design) akan tetapi sekaligus memanfaatkan sumber-sumber perpustakaan untuk memperoleh data penelitian.

Data-data yang didapatkan, kemudian dikumpulkan, dikompilasi, dikaji, dianalisis, dan disimpulkan sehingga mendapatkan rekomendasi mengenai studi literatur.

\section{HASIL DAN PEMBAHASAN}

\section{Perubahan Pola Pembelajaran di Masa Pandemi Covid-19}

Perubahan pola pembelajaran saat ini terlihat masif dilakukan mulai dari tingkatan sekolah dasar, menengah bahkan sampai perguruan tinggi. Organisasi PBB yang mengurusi pendidikan, keilmuan, dan kebudayaan UNESCO menyebutkan, lebih dari 1,5 miliar pelajar di dunia tidak bisa belajar di sekolah akibat virus asal Wuhan, China tersebut seperti yang dirilis oleh surat kabar Antaranews.com pada hari Sabtu, 11 April 2020. Masalah ini tentunya menuntut instansi 
pendidikan dan pendidik (guru dan dosen) yang menjadi garda terdepan untuk menerapkan proses pembelajaran yang tepat. Regulasi yang diterapkan oleh pemerintah dengan belajar di rumah, bekerja di rumah dengan menerapkan physical distancing (jaga jarak) agar Covid-19 tidak menyebar secara cepat diharuskan untuk belajar secara online/daring.

\section{Pembalajaran Online (E-Learning)}

Hasil riset terdahulu banyak yang menunjukkan kelebihan pembelajaran online (daring) dibandingkan pembelajaran secara tatap langsung atau konvensional. Seperti temuan hasil penelitian Nisa (2012) yang mengungkapkan bahwa rata-rata hasil belajar mata kuliah Statistik mahasiswa Tadris Bahasa Inggris Semester II Tahun Akademik 2010/2011 yang diajar dengan metode e-learning lebih baik dari pada rata-rata hasil belajar mahasiswa yang diajar dengan metode konvensional. Senada hasil penelitian Santoso (2009) yang menyatakan bahwa pembelajaran online memberikan pengaruh yang lebih tinggi daripada pembelajaran dengan menggunakan media LKS terhadap prestasi belajar kimia. Demikian juga dari hasil penelitian Mulyani (2013) yang menunjukkan bahwa pembelajaran berbasis e-learning berpengaruh terhadap hasil pembelajaran fisika pada konsep impuls dan momentum (hasil belajar siswa yang menggunakan pembelajaran e-learnin $g$ lebih tinggi dibandingkan dengan menggunakan pembelajaran konvensional).

Banyak aplikasi pembelajaran online yang bisa diterapkan dalam dunia pendidikan akhirakhir ini. Salah satu aplikasi gratis dan familiar diterapkan adalah aplikasi Google Classroom. Guru, dosen, tutor dan pengajar pada umumnya dapat membuka kelas dan mengundang peserta didik dalam kelas tersebut. Pembelajaran online dalam aplikasi tersebut dapat berlangsug dengan berbagai materi dan tugas yang diberikan oleh pengajar ke peserta didik. Pengajar pun dapat memberikan nilai terkait dengan tugas yang dikumpulkan secara rapi dan terarsip dengan baik. Pembelajaran online yang diterapkan memungkinkan pengajar dan peserta didik dapat melangsungkan pembelajaran tanpa melalui tatap muka di kelas dengan pemberian materi pembelajaran (berupa slide power point, e-book, video pembelajaran dll., tugas (mandiri atau kelompok), sekaligus penilaian. Pengajar dan peserta didik dalam aplikasi ini dimungkinkan untuk berinteraksi melalui forum diskusi (stream) terkait dengan permasalahan materi dan jalannya pembelajaran secara interaktif. Bahkan di akhirakhir ini pada aplikasi Google Classroom sudah include di dalamnya Google Meet yang memungkinkan untuk melakukan video teleconference (https://classroom.google.com). Sabran dan Sabara (2018) menyatakan pembelajaran google classroom sebagai media pembelajaran secara keseluruhan cukup efektif dengan tingkat kecenderungan sebesar 77,27\%. Hasil yang serupa didapatkan oleh, Sari (2019) mengungkapkan bahwa ada pengaruh signifikan dari kemudahan, kemanfaatan, dan kualitas layanan Google Classroom terhadap efektivitas pembelajaran.

Aplikasi lain yang bisa digunakan adalah Edmodo. Aplikasi ini hampir sama dengan Google Classroom yang memiliki fitur-fitur menarik seperti polling, gradebook, file and links, quiz, library, assignment, award badge, dan parent code. Kelebihan dari aplikasi ini dapat dipantau oleh orang tua secara simultan. Sehingga sangat cocok digunakan untuk peserta didik kelas dasar sampai menengah yang butuh kontrol lebih dari guru maupun orang tua (https://www.edmodo.com/). Efektifitas hasil penelitian terhadap penggunaan e-learning Edmodo dalam pembelajaran diungkapkan Suriadhi, dkk. (2014). Hasil penelitian mereka berdasarkan kualitas e-learning berbasis Edmodo pada mata pelajaran IPA pada hasil evaluasi para ahli (expert judgement) dan uji coba produk kepada siswa menunjukkan hasil yang sangat baik, serta Penggunaan e-learning berbasis Edmodo efektif untuk meningkatkan hasil belajar IPA pada siswa kelas VIII di SMP Negeri 2 Singaraja.

Selain dua flatform yang dapat diterapkan secara klasikal di atas, di tengah pandemi Covid19 ada 12 (dua belas) flatform terkenal untuk sumber belajar online gratis yang bisa diakses bebas oleh peserta didik maupun pengajar seperti yang tersaji pada Tabel 1. (Adit, 2020).

Sayangnya ada beberapa permasalahan yang dihadapi saat melakukan pembelajaran online terutama akses internet (paket data) dan belum terbiasanya pengajar dan peserta didik menggunakan aplikasi pembelajaran online. Sebagaimana yang diungkapkan dari hasil survey Gunawan et al. (2020) Kendala yang paling sering muncul selama pelaksanaan pembelajaran online yaitu paket internet yang tidak dimiliki mahasiswa, keterbatasan akses internet oleh dosen dan mahasiswa, dan belum terbiasanya dengan pembelajaran online. Sebagian besar 
dosen mengadakan pembelajaran dan diskusi melalui aplikasi socialmedia seperti WhatsApp. Beberapa ada yang memanfaatkan LMS Moodle daring yang dikembangkan universitas atau secara mandiri maupun Google Classroom. Sebagian pembelajaran online juga dilaksanakan melalui video conference dengan memanfaatkan aplikasi Zoom Cloud meetings. Penyampaian materi paling banyak dilakukan yaitu dengan membagi file melalui pesan WhatsApp dan socialmedia lainnya.

Tabel 1. Daftar Flatform Situs Pembelajaran Online Gratis di Indonesia

\begin{tabular}{|c|c|c|}
\hline No & Flatform & Alamat Situs \\
\hline 1 & $\begin{array}{l}\text { Rumah } \\
\text { Belajar }\end{array}$ & https://belajar.kemdikbud.go.id/ \\
\hline 2 & Meja Kita & https://mejakita.com/ \\
\hline 3 & Icando & https://bit.ly/appicando \\
\hline 4 & $\begin{array}{l}\text { Indonesia } \\
\mathrm{X}\end{array}$ & https://www.indonesiax.co.id/ \\
\hline 5 & $\begin{array}{l}\text { Google for } \\
\text { Education }\end{array}$ & https://edu.google.com/ \\
\hline 6 & $\begin{array}{l}\text { Kelas } \\
\text { Pintar }\end{array}$ & https://www.kelaspintar.id/ \\
\hline 7 & $\begin{array}{l}\text { Microsoft } \\
\text { Office } 365\end{array}$ & $\begin{array}{l}\text { https://www.microsoft.com/id- } \\
\text { id/education/products/office }\end{array}$ \\
\hline 8 & $\begin{array}{l}\text { Quipper } \\
\text { School }\end{array}$ & https://www.quipper.com/id/school/ \\
\hline 9 & Ruangguru & https://ruangguru.com/belajar \\
\hline 10 & Sekolahmu & https://www.sekolah.mu/kelasmu/ \\
\hline 11 & Zenius & https://www.zenius.net/ \\
\hline 12 & $\begin{array}{l}\text { Cisco } \\
\text { Webex }\end{array}$ & https://www.webex.com/ \\
\hline
\end{tabular}

(Sumber: Kompas.com)

Permasalahan akses internet dan jaringan tentunya menjadi perhatian yang serius bagi semua pihak. Mulai dari instansi pendidikan, pemerintah daerah maupun pusat, pengajar dan orang tua, untuk menyediakan layanan akses internet yang memadai agar proses pembelajaran online berjalan dengan optimal. Sebaik apapun flatform pembelajaran online, namun tanpa didukung dengan adanya jaringan internet, dampaknya tentu kurang optimal. Menjadi berita gembira beberapa operator seluler telah mengeluarkan program khusus akibat Covid-19 ini. Beberapa provider menggratiskan layanan internet untuk akses-akses tertentu, misalnya untuk situs-situs pendidikan sebagaimana yang diungkapkan oleh anggota DPR RI (Budiansyah, 2020). Langkah ini adalah salah satu wujud nyata yang hendaknya bisa diikuti dalam menyediakan fasilitas jaringan internet oleh semua pihak.
Pembelajaran online yang dilakukan dari temuan di atas menunjukkan masih belum familiarnya pendidik dan peserta didik dengan berbagai flatform yang ada. Sehingga lebih banyak mengakses pembelajaran online dengan media WhatsApp karena ini yang sudah terbiasa digunakan. Kasus ini tentunya menjadi rekomendasi untuk setiap pendidik dan peserta didik untuk mulai adaptif dan terus berpacu untuk belajar dalam mengakses berbagi flatform pembelajaran online yang tersedia agar proses belajar mengajar optimal sehingga hasil belajar yang diraih peserta didik juga bisa maksimal. Semua flatform yang ada sudah menyediakan tutorial penggunaannya. Bahkan di situs Youtube, sudah banyak youtuber yang mengupload berbagai tatacara menjadi guru dan siswa pada flatform pembelajaran online.

Hal yang terpenting dalam menerapkan pembelajaran online pada peserta didik seyogyanya memperhatikan berbagai aspek agar tujuan pembelajaran tercapai. Pembelajaran melalui sistem jaringan online ini sebagaimana dikemukakan Setyosari (2007) mencakup lima hal penting, yaitu: (1) isi yang disajikan memiliki relevansi dengan tujuan khusus pembelajaran yang ingin dicapai, (2) menggunakan metodemetode pembelajaran melalui contoh-contoh dan latihan-latihan untuk membantu belajar pebelajar, (3) menggunakan media seperti gambar-gambar dan kata-kata untuk menyajikan isi dan metode, dan (4) mengembangkan dan membangun pengetahuan dan keterampilan baru sesuai dengan tujuan individu dan peningkatan organisasi.

\section{Pembelajaran Berbasis Proyek}

Pembelajaran online yang disinergikan dengan basis pembelajaran yang tepat akan memberikan efek pembelajaran yang lebih optimal. Salah satu pendekatan pembelajaran yang dapat meningkatkan kompetensi peserta didik dari berbagai riset telah dilakukan adalah pembelajaran berbasis proyek. Interaksi dapat terjadi secara efektif dalam pembelajaran berbasis proyek dengan memanfaatkan proses penyelidikan dengan cara mengarahkan peserta didik untuk membuat atau mengembangkan produk yang aplikatif dan berkaitan dengan kehidupan sehari-hari. Secara khusus, pembelajaran berbasis proyek terdiri dari tugastugas berbasis penyelidikan yang membantu peserta didik mengembangkan pentingnya teknologi, sosial dan inti dari kurikulum (Sahin, 2013). Beberapa hasil riset yang menunjukkan 
keefektifan pembelajaran berbasis proyek diantaranya hasil penelitian Sucilestari dan Arizona (2018) yang mengungkapkan bahwa model pembelajaran berbasis proyek dapat meningkatkan kecakapan hidup mahasiswa. Peningkatan ini terjadi pada semua aspek kecakapan hidup yaitu kecakapan personal, kecakapan sosial, kecakapan akademik dan kecakapan vokasional. Model pembelajaran berbasis proyek menjadi alternatif model pembelajaran yang dapat diimplementasikan untuk membina kecakapan hidup mahasiswa di perguruan tinggi atau peserta didik di sekolah khususnya pada pembelajaran yang berkaitan dengan sains. Sejalan dengan hasil penelitian Chasanah et al. (2014) yang menemukan, pembelajaran dengan model project based learning lebih efektif daripada model pembelajaran konvensional dalam meningkatkan hasil belajar berupa kemampuan berpikir kreatif dan keterampilan proses sains siswa.

\section{Sinergi Pembelajaran Online Berbasis Proyek sebagai Solusi di Masa Pandemi Covid-19}

Noor, et al. (2017) mengungkapkan bahwa pembelajaran e-learning dalam pembelajaran berbasis proyek secara signifikan efektif dalam pencapaian sikap spritual, sikap sosial, proyek, produk dan ketuntasan belajar peserta didik. Berdasarkan berbagai hasil riset yang dipaparkan di atas pembelajaran online berbasis proyek dapat menjadi salah satu solusi dalam mengoptimalkan pembelajaran khususnya di tengah terjadinya pandemik Covid-19. Melalui pembelajaran online berbasis proyek peserta didik dapat melalui pembelajaran yang bermakna sehingga pengetahuan dan ilmu yang didapatkan memiliki arti yang dapat dimanfaatkan sebagai bekal mereka menjadi problem solver dari permasalahan yang dihadapi.

\section{KESIMPULAN}

Sistem pembelajaran online berbasis proyek memberikan banyak peluang untuk mengakses bahan ajar oleh warga pembelajar. Banyak flatform maupun media online yang bisa diakses melalui jaringan internet oleh pengajar maupun peserta didik. Beberapa hal yang menjadi kendala dalam penerapan pembelajaran online diantaranya kuota internet yang terbatas dan masih belum familiarnya tenaga pendidik beserta peserta didik dalam mengaplikasikannya. Sehingga perlu adanya upaya khusus yang lebih maksimal untuk mengatasi masalah ini dari semua pihak. Salah satu pendekatan pembelajaran yang dapat mengoptimalkan pembelajaran online adalah pembelajaran berbasis proyek. Pembelajaran ini memfasilitasi peserta didik untuk mempelajari konsep secara mendalam dan dapat meningkatkan hasil belajar.

\section{DAFTAR PUSTAKA}

Adit, A. (2020). 12 Aplikasi Pembelajaran Daring Kerjasama Kemendikbud, Gratis!. https://edukasi.kompas.com/read/2020/03 /22/123204571/12-aplikasi-pembelajarandaring-kerjasama-kemendikbudgratis?page $=$ all Diakses 28 April 2020

Chasanah, ARU, Khoiri,N. \& Nuroso, H. (2016). Efektivitas Model Project Based Learning terhadap Keterampilan Proses Sains dan Kemampuan Berpikir Kreatif Siswa pada Pokok Bahasan Kalor Kelas X SMAN 1 Wonosegoro Tahun Pelajaran 2014/2015. Jurnal Penelitian Pembelajaran Fisika. 7 (1), 19-24.

http://journal.upgris.ac.id/index.php/JP2F/ article/view/1149

DOI: http://dx.doi.org/10.26877/jp2f.v7i1 $\underline{.1149}$

Budiansyah, A. (2020). Internet Digratiskan Selama Wabah Corona di RI, Setuju?

https://www.cnbcindonesia.com/tech/202 00407180620-37-150401/internetdigratiskan-selama-wabah-corona-di-risetuju. Diakses 27 April 2020

Gunawan, Suranti, NMY. \& Fathoroni (2020). Variations of Models and Learning Platforms for Prospective Teachers During the COVID-19 Pandemic Period. Indonesian Journal of Teacher Education. $1(2), 61-70$ https://journal.publicationcenter.com/index.php/ijte/article/view/95/ $\underline{48}$

Hermann, M., Pentek, T. \& Otto, B. (2016). Design Principles for Industrie 4.0 Scenarios. Presented at the 49th Hawaiian International Conference on Systems Science. 
https://pdfs.semanticscholar.org/069c/d10 2faebef48fbb7b531311e0127652d926e.pd $\underline{\mathrm{f}}$

Kagermann, H., Lukas, W.D. \& Wahlster, W. (2013). Final report: Recommendations for implementing the strategic initiative INDUSTRIE 4.0. Industrie 4.0 Working Group.

https://www.din.de/blob/76902/e8cac883f 42bf28536e7e8165993f1fd/recommendati ons-for-implementing-industry-4-0data.pdf

Molinda, M. (2005), Instructional Technology and Media for Learning New Jersey Colombus, Ohio

Mulyani, W. (2013). Pengaruh Pembelajaran Berbasis E-Learning terhadap Hasil Belajar Siswa pada Konsep Impuls dan Momentum. Skripsi. Program Studi Pendidikan Fisika FTK UIB Syarif Hidaytullah Jakarta.

http://repository.uinjkt.ac.id/dspace/bitstre am/123456789/26232/3/WIWI\%20MUL

YANI-FITK.pdf

Nisa, LC. (2002). Pengaruh Pembelajaran ELearning Terhadap Hasil Belajar Mata Kuliah Statistics Mahasiswa Tadris Bahasa Inggris Fakultas Tarbiyah IAIN Walisongo. Jurnal Phenomenon 2(1), 726.

http://journal.walisongo.ac.id/index.php/P henomenon/article/view/416

DOI: http://dx.doi.org/10.21580/phen.201 2.2.1.416

Noor, ME., Hardyanto, W \& Wibawanto, H. (2017). Penggunaan E-Learning dalam Pembelajaran Berbasis Proyek di SMA Negeri 1 Jepara. Innovative Journal of Curriculum and Educational Technology 6 (1), 17-26.

https://journal.unnes.ac.id/sju/index.php/u jet/article/view/15572

Sabran \& Sabara, E. (2018). Keefektifan Google Classroom sebagai Media Pembelajaran. Prosiding Seminar Nasional Lembaga Penelitian Universitas Negeri Makassar "Diseminasi Hasil Penelitian Melalui Optimalisasi Sinta dan Hak Kekayaan Intelektual", 122-125 https://ojs.unm.ac.id/semnaslemlit/article/ view/8256

Sahin, A. (2013). STEM Project-Based Learning. Boston, USA: SensePublishers

Santoso, E. (2009). Pengaruh Pembelajaran Online Terhadap Prestasi Belajar Kimia Ditinjau Dari Kemampuan Awal Siswa. Tesis. Program Pasca Sarjana Universitas Sebelas Maret Surakarta. https://core.ac.uk/download/pdf/1235179 $\underline{3 . p d f}$

Sari, IN. (2019). Pengaruh Penggunaan Googleclassroom terhadap Efektivitas Pembelajaran Mahasiswa Universitas Islam Indonesia. Skripsi. Fakultas Ekonomi Universitas Islam Indonesia Yogyakarta.

https://dspace.uii.ac.id/handle/123456789 $\underline{113733}$

Setyosari, P. (2007). Pembelajaran Sistem Online: Tantangan dan Rangsangan. Majalah Ilmiah Pembelajaran 2, 1-10. https://journal.uny.ac.id/index.php/mip/art icle/view/5992

Sucilestari, R. \& Arizona, K. (2018). Peningkatan Kecakapan Hidup melalui Pembelajaran Sains Berbasis Proyek. Prosiding Seminar Nasional Pendidikan Biologi. 436-441.

http://www.jurnalfkip.unram.ac.id/index. php/SemnasBIO/article/view/700

Sucilestari, R. \& Arizona, K. (2018). Pengaruh Project Based Learning pada Matakuliah Elektronika Dasar terhadap Kecakapan Hidup Mahasiswa Prodi Tadris Fisika UIN Mataram. Konstan Jurnal Fisika dan Pendidikan Fisika, 3 (1), 26-35. https://jurnalkonstan.ac.id/index.php/jurn al/article/view/4

DOI: https://doi.org/10.20414/konstan.v3i $\underline{1.4}$

Suriadhi, Gede,. Tastra, I Dewa Kade. \& Suwatra, Ign. Wayan. (2014). Pengembangan E-LearningBerbasis Edmodopada Mata Pelajaran IPA Kelas VIII di SMP Negeri 2 Singaraja. Journal Edutech Universitas Pendidikan Ganesha, 2(1). 
Kurniawan Arizona et al. (2020). Jurnal IImiah Profesi Pendidikan, 5 (1): 64 - 70

DOI: 10.29303/jipp.v5i1.111

https://ejournal.undiksha.ac.id/index.php/J EU/article/view/3795/

DOI: http://dx.doi.org/10.23887/jeu.v2i1. $\underline{3795}$
Zed, M. (2014). Metode Penelitian Kepustakaan. Jakarta: Yayasan Obor Indonesia. 